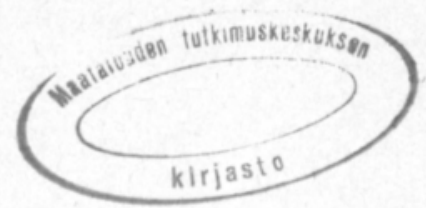

\title{
Suomalaisten lämminveristen kilpailukuntoisten ravihevosten veriarvoista
}

\author{
EsA KÄÄNTEE \\ 66270 Pörtom
}

\section{Hematological values of the Finnish warmblood trotters in racing condition \\ EsA KÄÄNTEE \\ 66270 Pörtom}

\begin{abstract}
In the present study the rest values of $\mathrm{Hb}$ and serum $\mathrm{Na}, \mathrm{K}, \mathrm{Fe}, \mathrm{TIBC}$, cholesterol, urat, creatinin, $\mathrm{Ca}, \mathrm{Mg}, \mathrm{P}, \mathrm{CPK}, \mathrm{AP}, \mathrm{TP}, \mathrm{GOT}, \mathrm{LDH}$ and glucose of 41 Finnish warmblood trotters in racing condition were measured. Collecting of blood was made after morning feeding. After $2 \mathrm{kms}$ heating the blood samples was collected for determination of $\mathrm{Hb}$ and SGOT exercise values.

The SGOT values increased in beginning of the training period and then returned to the original level when the horse was in good condition. Then was the differences of the rest and exercise values only $25 \%$. The SGOT values increased, when the horse was in overcondition.

The restvalues of $\mathrm{Hb}$ was followed the development of condition by part of horses.

The feeding causes clear variations in SAP. The increased calcium intake is followed by decreasing the SAP values.
\end{abstract}

\section{Johdanto}

Tieteellisen valmennuksen yhteydessä tapahtuva verinäytteiden tulkinta on osoittautunut vaikeaksi. Hevosten hematologisten normaaliarvojen vaihtelevuusalueet ovat laajat (WrLliamson 1974). Ruokinnallisten tekijöiden, suorituskyvyn ja valmennuksen lisäksi monet muut tekijät vaikuttavat veriarvoihin. Varsinkin hemoglobiiniarvot muuttuvat nopeasti veren nestemäärässä tapahtuvien vaihteluiden ja kiistellyn punasolureservin, noin 8 ltr soluja, lähtiessä liikkeelle pernasta, keuhkoista ja muista elimistä (ARCHER 1974).

Suoritetussa tutkimuksessa on määritetty suomalaisten lämminveristen kilpailukuntoisten ravihevosten ne veren ja seerumin normaaliarvot, jotka ovat tieteellisen valmennuksen kannalta tärkeitä. Kuukausitarkastusten yhteydessä on lisäksi seurattu hevosten suorituskyvyn, hemoglobiinin ja seerumin entsyymiarvojen muutoksia. 


\section{Aineisto ja menetelmät}

Aineisto käsittää kahden vuoden aikana kertyneet analyysitulokset 70:stä hevosesta. 27 hevosta on ollut pitempiaikaisen seurannan kohteena. Normaaliarvot on laskettu 41 hevosta käsittävästä otoksesta, hevoset ovat olleet valmentajien mielestä kilpailukunnossa. Hevoset ovat 6:sta eri tallista.

Verinäytteiden otto on suoritettu kuukauden väliajoin aamuruokinnan jälkeen hevosten ollessa karsinoissaan. Hemoglobiinin rasitusarvon $\left(\mathrm{Hb}_{\mathrm{r}}\right)$ määräämiseksi, kuten myös $\mathrm{SGOT}_{\mathrm{r}}$-arvon määräämiseksi, on verinäyte otettu välittömästi kahden kilometrin maksimaalisen ravin, hiitin, jälkeen sydämen lyöntitiheyden ollessa yli $100 / \mathrm{min}$.

Kuukausitarkastusten yhteydessä on määritetty hemoglcbinin lepoarvo $\left(\mathrm{Hb}_{1}\right)$ syanmethemoglobiinina, seerumin glutamiini-oksaalietikkahappo-transaminaasi (SGOT) REITMANin ja FRANKELin (1957) menetelmällä, seerumin alkaalinen fosfataasi (SAP) HUGGINsin ja TALAYn (1945) menetelmällä sekä seerumin valkuaisaineet (STP) WECHSELBAUмin (1946) menetelmällä. Veren laskeuma on määritetty 10:stä ml:sta verta 24 tunnin kuluttua, tulosta on vertailtu $\mathrm{Hb}_{1^{-}}$ arvoihin

Joka hevoselle on tehty perustutkimus, joka käsittää seerumin Ca:n, epäorg. P:n, Mg:n, Na:n, K:n, Fe:n, TIBC:n (raudansitomiskyvyn), kolesterolin, uraatin ja kreatiinin määritykset. Määritykset on uusittu tarvittaessa. Analyysit on suoritettu SMA 12/60 Autoanalysaattorilla ja Parker-Elmer atomiabsorptospektrofotometrilla työohjeiden mukaan. Seerumin sokeri on määritetty KEstovin (1956) menetelmällä.

Hevosten ruokintaa, valmennusta ja kilpailusuorituksia on seurattu ja vertailtu veriarvojen muutoksiin. Lihasvauriotapauksissa on seerumin kreatiniinifosfokinaasi (CPK) määritetty OLıverin (1955) menetelmällä ja laktaattidehydrcgenaasi (LDH) WrobLEwSKIn ja LAUDEn (1955) menetelmällä.

\section{Tulokset}

Tulokset perustutkimuksesta on esitetty taulukossa 1 sekä Hb:n ja SGOT:n lepo- ja rasitusarvot taulukossa 2 .

$\mathrm{Hb}_{\mathrm{r}}$ on starttikuntoisella hevosella $20-23 \mathrm{~g} / 100 \mathrm{ml}$, korkein mitattu arvo $24 \mathrm{~g}$. $\mathrm{Hb}_{\mathrm{t}}$ vaihtelee hevosen kunnosta ja hermostuneisuudesta johtuen paljon. Äärirajat ovat $8-17 \mathrm{~g} / 100 \mathrm{ml}$. Starttivalmillla lämminverisellä $\mathrm{Hb}_{1}$ on $14-16 \mathrm{~g}$. Laskeuma $10 \mathrm{ml} / 24 \mathrm{t}$ vaihtelee $4.2-6.3 \mathrm{ml}$ välillä seuraten hyvin $\mathrm{Hb}_{1}: \mathrm{n}$ vaihteluita.

$\mathrm{Hb}_{1^{-}}$ja laskeuma-arvoissa on hevoskohtaisten poikkeamien lisäksi tallikohtaista valmennuksesta ja ruokinnasta johtuvaa eritasoisuutta. Alhaiset $\mathrm{Hb}_{\mathrm{l}^{-}}$ arvot kuvastuvat huonoina kilpailusuorituksina.

SAP:n kohdalla on kullakin tallilla sille ominainen, hevosten kalsiumin saannista johtuva tasonsa, jossa on hevosten iästä johtuvia vaihteluita. Kasvukaudet aiheuttavat SAP:n nousun. Aineiston SAP:n-arvot vaihtelevat $4-22$ HU pääosan ollessa $12-14 \mathrm{HU}$.

Juuri maahan tuoduilla hyvinhoidetuilla hevosilla SAP-taso on ollut alhainen 5-6 HU. Myöhemmin SAP-taso on vähitellen kohonnut ruokinnallisten 
Taulukko 1. Kilpailukuntoisten lămminveristen ravurien veren $\mathrm{Hb}$ - sekä seerumin Fe-, TIBC-, Ca-, Mg-, P-, Na-, kolesteroli-, uraatti-, kreatiini-, sokeri-, GOT-, CPK-, AP- ja LDH-arvoja. Arvot ovat lepoarvoja. 41 hevosta.

Table 1. $\mathrm{Hb}$ and serum $\mathrm{Fe}, \mathrm{TIBC}, \mathrm{Ca}, \mathrm{Mg}, \mathrm{P}, \mathrm{Na}, \mathrm{K}$, cholesterol, urat, creatinin, glucose, $T P, G O T, C P K, A P, L D H$ and glucose values of trotting horses in racing condition. Values are taken in rest. 41 horses.

\begin{tabular}{|c|c|c|c|c|c|}
\hline & $\overline{\mathrm{x}}$ & $\mathrm{SD} \pm$ & & $\overline{\mathrm{x}}$ & $\mathrm{SD} \pm$ \\
\hline $\mathrm{Hb}_{1} \mathrm{~g} / 100 \mathrm{ml} \ldots \ldots \ldots \ldots$ & 13.8 & 1.9 & Urat ................... & 32 & 13 \\
\hline $\mathrm{Fe} \mu \mathrm{Mol} / 1 \ldots \ldots \ldots \ldots \ldots . . . . . .$. & 32.9 & 8.6 & Creatinin ............ & 138 & 17 \\
\hline TIBC $\ldots \ldots \ldots \ldots \ldots \ldots \ldots \ldots$ & 73.6 & 13.1 & Glucose $\mathrm{mg} \% \ldots$ & 72 & 8 \\
\hline $\mathrm{Ca} \mathrm{mMol} / 1$................ & 2.96 & 0.35 & TP $\mathrm{g} / 100 \mathrm{ml} \ldots \ldots$ & 6.28 & 0.3 \\
\hline 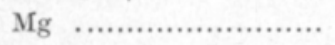 & 1.13 & 0.3 & GOT KU ........... & 234 & 139 \\
\hline 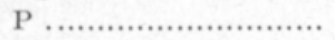 & 1.26 & 0.21 & CPK IU ............ & 167 & 147 \\
\hline Na & 140.7 & 2.8 & LDH W.U. ......... & 139 & 21.7 \\
\hline K ......................... & 3.6 & 0.7 & AP $\mathrm{HU} \ldots \ldots \ldots \ldots$ & 11.1 & 2.6 \\
\hline Cholesterol ................ & 2.6 & 0.5 & & & \\
\hline
\end{tabular}

Taulukko 2. Kilpailukuntoisten lämminveristen ravurien Hb- ja SGOT-arvot levossa ja välittömästi $2 \mathrm{~km}: \mathrm{n}$ hiitin jälkeen. 30 hevosta.

Table 2. The $\mathrm{Hb}$ and SGOT ranges of horses in rest and after exercise. 30 horses.

\begin{tabular}{|c|c|c|c|c|}
\hline & \multicolumn{2}{|c|}{$\begin{array}{l}\text { Lepoarvo } \\
\text { In rest }\end{array}$} & \multicolumn{2}{|c|}{$\begin{array}{l}\text { Rasitusarvo } \\
\text { After exercise }\end{array}$} \\
\hline & $\overline{\mathrm{x}}$ & $\mathrm{SD} \pm$ & $\overline{\mathrm{x}}$ & $\mathrm{SD} \pm$ \\
\hline $\mathrm{Hb} \mathrm{g} / 100 \mathrm{ml}$............... & 14,5 & 1.5 & 21.1 & 1.3 \\
\hline SGOT KU ................... & 210 & 110 & 295.8 & 250 \\
\hline
\end{tabular}

tekijöiden johdosta maamme hevosille tyypilliselle tasolle $12-14$ HU. SGOT:n vaihtelut tässä aineistossa ovat hyvin laajat $80-4500 \mathrm{KU}$. Starttihevosella SGOT on suuruusluokkaa $200 \mathrm{KU}$. Kohonneita arvoja on huonosti valmennetuilla, ylikuntoisilla $(400-500 \mathrm{KU})$ sekä erilaisista lihasvaurioista, kuten lannehalvauksesta ja tying up-syndromasta kärsivillä yksilöillä.

S-CPK-arvot ovat terveillä hevosilla $30-100$ UI. Akuutin lihasvaurion ja tying up-syndroman yhteydessä on todettavissa arvoja $1000-3000$ UI. STParvot vaihtelevat rajoissa $5.5-7.6 \mathrm{~g} / \mathbf{1 0 0} \mathrm{ml}$. Ruokinta vaikuttaa STP-arvoihin. Heinästä ja kaurasta koostuvalla ruokinnalla hevosten STP-arvot ovat 5.9$6.1 \mathrm{~g}$. Valkuaislisä kohottaa STP-pitoisuuden tasolle $6.5 \mathrm{~g}$. Kesäruokinnalla, hevosten saadessa tuoretta ruohoa, seerumin TP on $6.5-6.8 \mathrm{~g}$.

\section{Tulosten tarkastelu}

Tutkitut hevoset olivat kilpailukuntoisina yksilöinä terveitä, joten analyysien tulokset ovat yleensä normaalien vaihtelevuusrajojen sisällä. Tutkimusten tarkoituksena tieteellisessä valmennuksessa oli seurata hevosen (yksilön) kunnon kehitystä, todeta mahdolliset puutteet sekä edesauttaa hevosta saavuttamaan sen perinnöllisten tekijöiden edellyttämä suoritustaso. Analyysituloksiin vaikuttivat monet tekijät, joten johtopäätökset oli tehtävä hevosen kliinisen tilan, 
suorituskyvyn, valmentajan tekemien havaintojen, valmennusmenetelmien, edellisten analyysitulosten ja myös tallin muiden hevosten veriarvojen pohjalta. Johtopäätökset oli tehtävä, kuten ARCHER (1974) toteaa, yksilökehtaisesti.

Hemoglobiini. Elimistön mukautuessa rasitukseen $\mathrm{Hb}$ kohoaa. PERsson (1969) on osoittanut $\mathrm{Hb}_{\mathrm{r}}: \mathrm{n}$ ja suorituskyvyn välillä selvän yhteyden.

Hyväkuntoisella hevosella $\mathrm{Hb}_{\mathrm{r}}$ on noin $20 \mathrm{~g} / 100 \mathrm{ml}$ (Persson 1969, SchneiDER 1971). Tässä aineistossa oli todettavissa, että hyvään suorituskykyyn liittyi korkea $\mathrm{Hb}$. Suoritusten perusteella todettiin hevosen olevan huippukunnossa $\mathrm{Hb}_{\mathrm{r}}$ :n ollessa $22 \mathrm{~g}$ tai yli. Korkein tavattu arvo oli $24 \mathrm{~g} / 100 \mathrm{ml}$. Starttikuntoisten hevosten $\mathrm{Hb}_{\mathrm{r}}$ :n keskiarvo oli $21.1 \pm 1.3$ eli hieman korkeampi kuin Perssonin ja Schneiderin toteama. $\mathrm{Hb}_{\mathrm{r}}$-arvoihin voitiin vaikuttaa niiden ollessa alhaiset lisäämällä harjoitusten määrää ja rasittavuutta.

Rasitusarvojen oton tuottaessa vaikeuksia kuukausitarkastusten yhteydessä käytettiin usein $\mathrm{Hb}_{1}$-arvoa. Persson (1969) on todennut ettei $\mathrm{Hb}_{1}$ anna tietoja kilpailukunnosta, vaan ainoastaan anemiatapauksista. Veren punasolukonsentration nopeat vaihtelut eri tekijöiden, kuten hermostuneisuuden johdosta aiheuttavat suuria poikkeamia $\mathrm{Hb}_{1}$-arvoihin, vaikka näytteenotto-olosuhteet ja menetelmät olisivatkin standardisoidut. Toisaalta SchneIder (1971) toteaa $\mathrm{Hb}_{1}: \mathrm{n}$ kohoavan suorituskyvyn parantuessa ja kilpailukunnossa olevan hevosen $\mathrm{Hb}_{1}: \mathrm{n}$ olevan luokkaa $14-16 \mathrm{~g} / 100 \mathrm{ml}$.

Tämän aineiston $\mathrm{Hb}_{1}$-arvot vaihtelivat välillä $8-17 \mathrm{~g} / 100 \mathrm{ml}$. Hyväkuntcisilla valmentamattomilla yksilöillä $\mathrm{Hb}_{1}$ oli suuruusluokkaa 11-12 g. Suorituskyvyn parantuessa $\mathrm{Hb}_{1}$ kohosi tasolle $14-16 \mathrm{~g}$. Vastaava nousu oli todettavissa myös $\mathrm{Hb}_{\mathrm{r}}: \mathrm{n}$ kohdalla. Kuitenkin eräillä hevosilla $\mathrm{Hb}_{1}$ kohosi vain $0.5-1 \mathrm{~g}$, mutta suorituskyky nousi tyydyttävästi, kuten myös $\mathrm{Hb}_{\mathrm{r}}$. Näissä tapauksissa lisäys tapahtui punasolureservin kohdalla. $\mathrm{Hb}_{\mathrm{r}}$ - ja $\mathrm{Hb}_{1}$-arvojen ero oli normaalisti noin $50 \%$, mutta näillä hevosilla ero oli $100 \%$, lepoarvon ollessa luokkaa $11 \mathrm{~g}$ ja rasitusarvon $22 \mathrm{~g}$. Tällöin $\mathrm{Hb}_{1}$ ei antanut oikeaa kuvaa suorituskyvyn muutoksista.

$\mathrm{Hb}_{1}: \mathrm{n}$ ja $\mathrm{Hb}_{\mathrm{r}}: \mathrm{n}$ määritysten yhteydessä saadut tulokset ja tehdyt havainnot osoittivat $\mathrm{Hb}_{1}: \mathrm{n}$ kehityksen seuraamisen olevan pääosalla hevosista sopivan keinon suorituskyvyn muutosten seuraamiseen.

Näytteenoton yhteydessä on huomioitava hevosen hermostuneisuus ja määrityksiä täydennettävä $\mathrm{Hb}_{\mathrm{r}}: l l a ̈$.

Laskeuma. Veren laskeuma määritettynä $10 \mathrm{ml}$ :sta verta 24 tunnin kuluttua seurasi erittäin hyvin $\mathrm{Hb}_{1}$ : n mutoksia antaen karkean arvion punasolujen

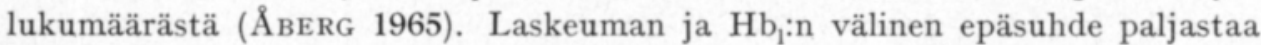
poikkeamat punasolujen koossa ja normaalissa hemoglebinipitoisuudessa. Aineiston laskeuma-arvot $4.2-6.3$ olivat normaalilla alueella.

SGOT. Hevosen SGOT:n normaalialueeksi ilmoitetaan 150-350 Karmen yksikköä (KU) (Lindholm 1973) tai $148 \pm 29$ IU (Simensen 1972) tai 231-358 IU (ANDERSON 1975). SGOT-ä̃vojen päivittäisen normaalin vaihtelun lisäksi on todettu tiettyjä säännönmukaisia muutoksia, joiden syynä ovat lihaksiston muutokset valmennuksen johdosta sekä lihaksiston sairaudet. Hevosen kilpailukunnon ja rasituskestävyyden todetaan kuvastuvan SGOT-arvoissa (ScHNEIDER 1971, Anderson 1975). Levossa olevan valmentamattoman hevosen SGOT on suuruusluokkaa $200 \mathrm{KU}$. 
Kun hevosta rasitetaan, niin arvo kohoaa hucmattavasti rasituksen johdosta $(100-200 \%)$ ja jopa tasolle $400 \mathrm{KU}$. SGOT:n kohoamista tapahtuu myös aloitettaessa valmennus, jolloin syynä saattaa olla lihassolujen vaurioituminen. Ylipitkät kuljetukset lihasvaurioineen kuvastuvat SGOT-arvoissa (CoDAzza ym. 1974). Elimistön tottuessa liikuntaan ja kunnon parantuessa SGOT-arvot laskevat alkuperäiselle tasclleen. Hyväkuntoisella hevosella ovat rasituksen aiheuttamat muutokset SGOT-arvoissa pieniä. Nousu on $20 \%$ :n suuruusluokkaa. Liikaa kilpailleella ja ylikuntoon valmennetulla hevosella SGOT kohoaa tasolle $500 \mathrm{KU}$, ennen kuin muut merkit kilpailuväsymyksestä, kuten huonot suoritukset, huene ruokahalu ja kiilloton karva näkyvät.

Edellä kuvatun kaltaiset muutokset SGOT-arvoissa cli todettavissa tämän aineiston hevosissa. Käytännössä osoittautui kohonneiden SGOT-arvojen syiden selvittely ja hoito suurimerkitykselliseksi hevosen kilpailukauden onnistumiselle. Ajoissa todetut ylikuntoisuustapaukset (SGOT:n nousu) normaloituvat parin viikon levolla.

Rutiinitarkastusten yhteydessä paljastuneet useat lannehalvaus- ja tying up-tapaukset selittävät aineistessa esiintyneen suuren SGOT-arvojen vaihtelun $(80-4500 \mathrm{KU})$. SGOT-arvojen lasku ns. normaalialueelle tapahtui yleensä kahden - neljän viikon levon jälkeen, kuten CoRnelıus ym. (1963) ja LindHOLM (1973) ovat todenneet. Riittävän pitkän lepokauden takaamiseksi lihasvaurioja ylikuntoisuustapauksissa SGOT:n määritys oli hyvä keino. SGOT:n lepoarvoiksi saatiin $234 \pm 139 \mathrm{KU}$ ja $210 \pm 110 \mathrm{KU}$. SGOT:n rasitusarvoksi saatu $294 \pm 249 \mathrm{KU}$ oli $1 / 4$ suurempi kuin lepoarvo (taulukot 1 ja 2). Kunmassakın taulukossa oli mukana tyypillisiä tying up-hevosia, joiden seerumin CPK- ja GOT-arvot olivat normaalin yläpuolella. Keskiarvot olivat LindHoLmin ilmoittamalla alueella. Lepo- ja rasitusarvojen välinen ero vastasi RoHRMANin (vrt. SCHNEIDER 1971) toteamaa poikkeamaa.

$C P K$. Aineistoon sisältyvien, kilpailukuntoisina pidettyjen hevosten S-CPK:n keskiarvoksi tuli $167 \pm 147 \mathrm{IU}$. Tulos poikkeaa AndERsonin (1975) tuloksesta, joka oli $73 \pm 7$ ja CodAzzan (1974) tuloksesta 93.5 sekä Lindholmin (1973) 3-25 sigmayksikköinä ilmoittamista normaaliarvoista. Syynä poikkeamaan olivat aineiston tying up-hevoset, joiden S-CPK ja SGOT-arvot olivat kohonneet. Lihasspesifisenä ja SGOT:ta nopeammin seerumista poistuvana CPK soveltui hyvin akuuttien lihasvaurioiden ja tying up-tapauksien toteamiseen ja paranemisprosessin seurantaan. ANDERSON on todennut S-CPK-arvoissa samantapaisia lihaksiston suorituskyvystä johtuvia muutoksia kuin SGOT:n kohdallakin on havaittu.

Sekä CPK:n että GOT:n vapautuminen lihassolusta johtuu solun vaurioitumisesta tai solukuolemasta, jolloin solua ympäröivän sarkolemman läpäisykyky muuttuu ja entsyymit joutuvat seerumiin. Wrogemannin ja Penan (1976) esittämän hypoteesin mukaan hapenpuutteen, verenpuutteen, mitokondriovaurioiden tai ankaran lihastyön johdosta syntyvä energian puute vahingoittaa sarkolemmaa ja solua.

Mitokondrioiden kalsiumtasapainoa säätelevän toiminnan loppuessa energian puutteeseen kohoaa lihassolun Ca-pitoisuus ja lihassäikeet supistuvat erittäin voimakkaasti. Tällöin solu kuolee ja entsyymit vapautuvat. 
$S A P$. Hevosen SAP:n normaaliarvoiksi ilmoittaa Eläinlääketieteellisen korkeakoulun keskuslaboratorio 130-310 IU. Sova ym. (1965) ovat todenneet 1-2-vuotiailla hevosilla arvoiksi $12.2 \mathrm{HU}$ ja yli 5-vuotiailla $4.2 \mathrm{HU}$. Tässä aineistossa vaihtelivat SAP-arvot välillä $4-22 \mathrm{HU}$ johtuen ikärakenteen ja ruokinnan suurista vaihteluista. SAP-arvoihin vaikuttavista tekijöistä tärkein ja huomionarvoisin on luuston osteoblastien toiminta (BENGTSSON 1974) eli luuston kasvun ja mineraaliaineenvaihdunnan vilkkaus, jonka toteamiseksi SAP:n määritykset suoritetaan. SAP-arvoihin vaikuttavina tekijöinä ovat tällöin kalsiumin, fosforin ja D-vitamiinin saanti sekä hevosen kasvukaudet.

SAP-arvot vaihtelivat talleittain ja arvot olivat kussakin tallissa omalla tasollaan. Tavallisimmat tasot olivat 5-6 HU sekä $9-13$ ja $14-16 \mathrm{HU}$. Hevosten rehun kivennäispitoisuuden laskiessa SAP-arvot kohosivat. Kalsiumpitoisuutta lisäämällä saatiin SAP laskemaan.

Hyväkuntoiset starttivalmiit maahantuodut hevoset olivat tasolla 5-6 HU, mutta parissa kuukaudessa SAP kohosi samalle tasolle kuin tallin muillakin hevosilla. SAP:n kohoaminen johtui kalkkiköyhän ruokinnan aiheuttamasta luuston mineraalipitoisuuden vähenemisen johdosta vilkastuneesta osteoblastien toiminnasta. Luuston mineralisaation nopea lasku johtaa muutoksiin luustossa ja nivelissä, jotka yhdessä valmennuksesta johtuvan rasituksen kanssa voivat aiheuttaa pysyviä vikoja (KNUDSEN ym. 1968). KNUDSEN ym. ovat todenneet tallikohtaisten SAP-tasovaihteluiden lisäksi selviä vaihteluita eri hevoskasvatusalueilla johtuen erilaisista ruokintatottumuksista. SAP:n määrittäminen kuukausitarkastusten yhteydessä auttoi nuorten hevosten kasvukausien toteamisessa.

Kasvukauden aikana SAP-arvoissa oli todettavissa 2-4 HU:n nousu. Tällöin hevosen valmennus keskeytettiin tai sen rasittavuutta vähennettiin. Lisảksi SAP täydensi toisen epäspesifisen entsyymin SGOT:n määrityksiä auttamalla maksasairauksien eliminoinnissa (RATLIFF ym. 1972). SAP-arvojen tallikohtaisten vaihtelujen perusteella voitiin päätellä, ettei heinä-kauraruokinta takaa riittävää kivennäisten saantia, ja etteivät hevoset käytä riittävästi hyväkseen vapaasti tarjottuja kivennäisiä. Havainnot olivat samanlaiset kuin Kossila ym. (1972) sekä Schryver ja Hintz (1972) ovat todenneet. Kivennäisseos on lisättävä väkirehuihin (HINTz ja Schryver 1976).

$S T P$. Seerumin kokonaisproteinimäärän kohdalla aineistossa esiintyi suuria vaihteluita tallikohtaisesti sekä pitempinä ajanjaksoina myös hevoskohtaisesti. Vaihtelurajat olivat $5.5-7.6 \mathrm{~g} / \mathbf{1 0 0} \mathrm{ml}$. Talviruokinnalla (heinä + kaura) STP-arvot olivat 5.9-6.1. Hevosten saadessa väkirehuseoksia STP-arvot kohosivat 6.3-6.5 g tasolle. Jos ruokintaan kuului soijaa tai runsaasti leseitä, olivat STP-arvot selvästi kohonneet $(6.5-6.8 \mathrm{~g} / 100 \mathrm{ml})$. Kesäruokinnalla, hevosten saadessa proteiinirikasta tuoretta ruchoa, saavutettiin sama taso. Vaihtelut johtuivat, kuten FonNEsBeck ja Symons (1969) ovat todenneet, rehun proteiinipitoisuuden vaihteluista.

Ruokinnan korjausten päämääränä oli STP:n nostaminen tasolle 6.6 g, jota pidetään hevoselle normaalina (Sova ym. 1965). Ennen ruokinnan muutoksia tutkittiin tallin muiden hevosten STP-pitoisuudet. Mikäli ne olivat samanlaisella ruokinnalla olevilla muilla hevosilla normaalit, kiinnitettiin päähuomio potilaan hampaisiin ja suoliston bakteerikannan mahdollisiin häiriöihin, joita esiintyi 
ruokinnan muutosten yhteydessä. Nämä näkyivät selvinä muutoksina ulosteiden kiinteydessä ja hajunmuutoksissa. Hoitotoimenpiteinä käytettiin bakteerikannan uusimista joko koliviljelmän, piimän tai terveen hevosen suolen sisällön avulla.

Myös STP:n määrityksissä on otettava huomioon liikunnan vaikutus. Lihaksiston toiminta lisää seerumin proteiinikonsentratiota. Lihaksiston aineenvaihduntatuotteet lisäävät pienimolekyylisinä osmoottista painetta verisuonten ulkopuolella. Seerumista poistuu nestettä ja STP sekä Hb kohoavat. Lihastyö polttaa osan seerumin proteineista erityisesti $\beta$-globuliinia. Palautuminen normaalitilaan kestää noin 60 min., lukuunottamatta $\beta$-globuliinia, jonka suurta kulutusta intersellulaariset varastot eivät pysty niin nopeasti korvaamaan. Nestetasapainon saavuttamiseen vaikuttaa myös työn jatkuessa seerumiin tulevien palamisjätteiden seerumin osmoottista painetta lisäävä vaikutus (LANNE ym. 1958). RAJAKoski ym. (1973) ja CodAzzA ym. (1974) ovat todenneet rasitusarvon olevan $0,5 \mathrm{~g}$ lepoarvoa korkeamman.

Makrokivennäiset. Seerumin Ca-, P-, Mg-, Na- ja K-arvot keskiarvoina vastasivat Kossilan ym. (1973) ja Srmensenin (1973) ilmoittamia arvoja. Pääosa arvioista oli Eläinlääketieteellisen korkeakoulun keskuslaboratorion ilmoittamien normaaliarvojen: $\mathrm{Ca} 2.7-3.3, \mathrm{P} 0.58-1.29, \mathrm{Mg} 0,6-1.0, \mathrm{Na} 129-145$ ja K 3.2-4.6 mMol/1 rajoissa. Williamson (1974) on todennut Na:n ja K:n kohdalla tapahtuvien normaaliarvojen rajoihin sopivien pienienkin muutosten suuren merkityksen suorituskyvylle. Suorituskyky on parhaimmillaan Naarvojen ollessa $139-143$ ja K-arvojen $3.7-4.0 \mathrm{mMol} / \mathrm{l}$. Na- ja K-arvoihin vaikuttavat dehydratio, hikoilu, munuaissairaudet ja lisämunuaisen kuorikerroksen toimintahäiriöt (Cosgrove 1969, Williamson 1974).

Mikrokivennäiset. Seerumin Fe-pitoisuus vaihteli aineistossa välillä $14-$ $57.5 \mu \mathrm{Mol} / 1$ keskiarvon ollessa $32.9 \pm 8.6$. Seerumin TIBC vaihteli välillä $51-$ $90 \mu \mathrm{Mol} / 1$ keskiarvon ollessa $71.6 \pm 13.1$. Tulokset vastaavat Sovan ym. (1965), Kossilan ym. (1972) ja RaJAKosken ym. (1973) tuloksia.

Seerumin rautapitoisuuden alittaessa $25 \mathrm{mMol} / 1$ liitettiin hevosten ruokintaan rautalisä. Suun kautta annettu hoito tehosi kaikissa tapauksissa ja seerumin Fe-pitoisuus kohosi nopeasti normaalitasolle.

Typelliset aineet ja sokeri. Seerumin kolesteroli, uraatti, kreatiniini ja sokeriarvot vastasivat Kossilan ym. (1973), Sovan ym. (1965) ja Simensenin (1973) ilmoittamia tutkimustuloksia.

\section{Tiivistelmä}

Suoritetuissa tutkimuksissa on määritetty suomalaisten kilpailukuntoisten lämminveristen ravihevosten $(41 \mathrm{kpl})$ veren $\mathrm{Hb}-$ sekä seerumin $\mathrm{Na}-, \mathrm{K}-, \mathrm{Fe}-$, TIBC-, kolesteroli-, uraatti-, kreatiini-, CA-, Mg-, P-, CPK-, AP-, TP-, GOT-, sokeri- ja LDH-arvot keskiarvoineen ja poikkeamineen. Näiden lepoarvojen määritys on tapahtunut heti aamuruokinnan jälkeen otetuista verinäytteistä. Hb:n ja SGOT:n rasitusarvot $(30 \mathrm{kpl})$ on määritetty $2 \mathrm{~km}: \mathrm{n}$ hiitin jälkeen välittömästi otetusta näytteestä.

Pitempiaikaisessa seurannassa on todettu SGOT-arvojen kohoavan valmennuskauden alkaessa ja laskevan alkuperäiselle tasolleen suorintakyvyn paran- 
tuessa ja elimistön tottuessa rasitukseen. Hyväkıntoisella yksilöllä on lepoja rasitusarvojen välinen ero ollut vain $25 \%$ :n suuruusluokkaa. Ylikuntoisilla yksilöillä SGOT-taso nousee.

Hb:n lepoarvon seuraaminen antaa osalla hevosista hyvän kuvan suorituskyvyn kehityksestä.

SAP:n kohdalla on todettu selvät ruokinnasta johtuvat tallikohtaiset vaihtelut. Rehun Ca-pitoisuuden lisääminen on johtanut SAP:n laskuun.

Kiitãn maisteri Jouko Haapalahtea Oulun Diakonissalaitoksen laboratoriosta makro- ja mikromineraalien määrityksistä.

\section{KIRJALLISUUSLUETTELO}

Anderson, M. G. 1975. 1975. The influence of exercise in serum enzyme levels in the horse. Equine Veter. J. 7: 160-165.

Archer, R. K. 1974. Haematology in relation to performance and potential. J. S. Afr. Veter. Assoc. 45: 273-277.

Bengtsson, G. 1974. Metaboliska skelettsjukdomar hos häst. Nord. Veter. Kongr. 12: 125128.

Codazza, D., Maffeo, G. \& Reclaelli, G. 1974. Serum enzyme changes and haematochemical levels in thoroughbreds after transport and exercise. J. S. Afr. Veter. Assoc. 45: 331334.

Cornelius, C. E., Burnham, L. G. \& Hill, H. E. 1963. Serum transaminase activities of thoroughbred horses in training. J. Amer. Veter. Med. Assoc. 142: 639-642.

Cosgrove, J. S. 1969. The practical application of haematology 1. Equine Veter. J. 1: 194202.

LANne, R. de., Barnes, J. \& Brouha, L. 1958. Changes in concentration of plasma protein fractions durig muscular work and recovery. J. Appl. Phys. 13: 97-104.

Fonnesbeck, B. \& Symons, L. 1969. Effect of diet on concentration of protein, urea, nitrogen, sugar and cholesterol of blood plasma of horses J. Anim. Sci. 28: 216-219.

Hintz, H. F. \& Schryver, H. F. 1976. Nutrition and bone development in horses. J. Amer. Veter. Med. Assoc. 168: 39-44.

Huggins, C. \& Talalay, P. 1945. Sodium phenolphtalein phosphate as substrate for phosphatase tests. J. Biol. Chem. 159: 399-410.

Keston, A. 1956. Specific colorometric enzymatic analytical reagents for glucose. Abstr. 129 th Meet. Amer. Chem. Soc. Sect. 31 C 142.

KnUdSEn, O. \& Åsherm, A. 1968. Hälsokontrollens journaler berättar. Trav och galopp 8: $115-119$.

Kossila, V., TanhuanpäÄ, E., Virtanen, E. \& Luoma, E. 1973. Ratsuhevosten veren hemoglobiini-, glukoosi- ja seerumin kolesteroli-, kivennäis- ja hivenainepitoisuuksista J. Scient. Agric. Soc. Finl. 44: 249-257.

- - Virtanen, E. \& MavkKonen, J. 1972. Heinä-kaura dieetti ratsuhevosten energian, sulavan raakavalkuaisen sekä kivennäis- ja hivenaineiden lähteenä. J. Scient. Agric Soc. Finl. 44: 217-227.

Lindholm, A. 1973. Muskulatur - Hästens motor. Trav och galopp. Julnr.: 86-87.

Olrver, I. T. 1955. Spectrophotometric method for the determination of creatine phosphokinase and myokinase. Biochem. J. 61: 116.

Persson, S. 1969. Value of hemoglobin determination in the horse. Nord. Veter. Med. 21: $513-523$.

RajAKoski, E., Mero, M. \& Valtonen, M. 1973. Serum iron and total ironbinding capacity of the serum in trotters. Equine Veter. J. 5: 10-11. 
Ratliff, C., F. Hall, W. Culp, R. Gevedon, C. \& Westfall. 1972. The differentiation of hepatic and skeletal alkaline phosphatase by thermofractionation. Am. J. Castroent. 58: $22-29$.

Reitman, S. \& Frankel, S. 1957. A colotimetric method for the determination of serum glutamic oxalacetic and pyruvix transaminases. Amer. J. Clin. Path. 28: 56-63.

SchneIder, J. 1971. Zur Problematik des wissenschaftlichen Trainings bei Sportpferden. Mon. Veter. Med. 26: $948-952$.

SChryver, H. \& Hintz, H. 1972. Calcium and Phosphorus requirements of the horse. Rev. Feedstuffs 10: 35-38.

SIMENSEN, M. G. 1973. Some clinical-chemical values in normal thoroughbreds and trotters. Nord. Veter. Med. 24: 85-90.

Sova, J., Jiсна, J. \& Комавек, J. 1965. Die hämatologischen und biochemischen Normalwerten beim Pferd. Berl. Münch. tierärztl. Wschr. 78: 144-147.

Wechselbaum, T. E. 1946. Serum protein and biuret reagent. Amer. J. Pathol. 7: 40.

Williamson, H. 1974. Normal and abonormal electrolyte levels in the racing horse and their effect on performance. J. S. Afr. Veter. Assoc. 45: 335-340.

Wroblewski, F. \& LAUde, J. 1955. Lactic dehydro genase activity in blood. Proc. Soc. Exp. Biol. \& Med. 90: 210.

Wrogemann, K. \& Pena, S. D. J. 1976. Mitochondrial calcium overlo general mechasi for cell- necrosis in muscle diseases. Lancet I: 672-673.

ÅberG, B. 1965. Kompendium i klinisk kemi. 27 p. Stockholm.

Käsikirjoitus saapunut 25.11.1976 